Roman Jakobson:

\title{
Remarks on the Phonological Evolution of Russian in Comparison with the Other Slavic Languages.
}

Translated and annotated by Ronald F. Feldstein. Cambridge, MA - London: The MIT Press. 2018. XXIV $+215 \mathrm{~s}$.

ISBN 9780262038690

Jakobsonovu průkopnickou práci Remarques sur l'évolution phonologique du russe comparée à celle des autres langues slaves není třeba představovat. Ted' byla přeložena do angličtiny (a to z vydání v Jakobsonových Selected Writings, srov. s. 165 a 166). Překladatel píše, že je to „the first opportunity for many linguists to become acquainted with a major early work by Jakobson, filling a long-standing, unfortunate gap in the linguistic literature" (s. XIII). To je jistě pravda, jen bychom snad poznamenali, že kdo chce dělat lingvistiku, měl by umět číst francouzsky.

Překladatel svému překladu předeslal stručný úvod; v něm píše o účelu Jakobsonova pojednání, jímž bylo ukázat, že i diachronie je systémová, o diskusi o Remarques mezi Trubeckým a Jakobsonem a o Jakobsonově metodologii, postavené na pojmu distinktivního rysu (Translator's Foreword: The Significance of Roman Jakobson's Remarks on the Phonological Evolution of Russian in Comparison with the Other Slavic Languages; s. XIII-XVII). K předmluvě připojil také stručné poznámky vysvětlující neslavistickému publiku, co jsou základní otázky vývoje praslovanské fonologie (Notes on Early Common Slavic to Late Common Slavic; s. XIX-XXI). Každou kapitolu pak překladatel doprovodil anotacemi, přinášejícími různě hluboký, ale obecně spíš minimalistický komentář k jednotlivým oddílům Jakobsonovy knihy a někdy také k vývoji užívaných termínů nebo prezentovaných názorů.

Co v publikaci postrádáme, je zejména následující: dobová reflexe Jakobsonovy knihy; reflexe Jakobsonovy knihy v rámci pražské školy, př́ípadně šířeji v rámci funkcionalistické fonologie; reflexe prací k obecným aspektům Jakobsonovy metodologie a konkrétně diskuse Jakobsonových Remarques v nich. Snad se těchto témat ujmou př́ští badatelé, podnícení tímto ne sice převratným, ale přece jen záslužným publikačním počinem. Překladateli za jeho námahu děkujeme.

\section{Bohumil Vykypèl}

Czech Language Institute of the CAS, v. v. i.

Veveří 97, 602 oo Brno

Czech Republic

vykypel@ujc.cas.cz 